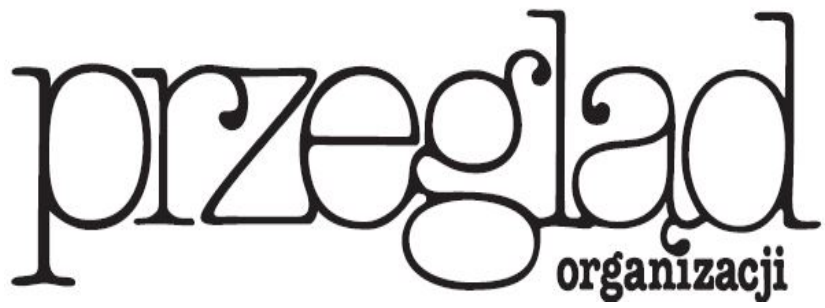

Miesięcznik TNOiK

Założył Karol Adamiecki w 1926 r.

\title{
KOMPETENCJE UCZESTNIKÓW PROJEKTU W ŚWIETLE BADAŃ EMPIRYCZNYCH
}

https://doi.org/10.33141/po.2019.08.06

\section{Maciej Brzozowski, Paweł Bartkowiak}

\section{Wprowadzenie}

$\mathbf{R}$ osnąca popularność projektów we współczesnej rzeczywistości gospodarczej zwraca uwagę na znaczenie zespołów projektowych - w tym szczególnie kierownika projektu - dla powodzenia realizowanych przedsięwzięć.

W literaturze przedmiotu można odnaleźć propozycje zestawów oczekiwanych wymagań wobec uczestników projektów. Jednym z obszarów szczególnego zainteresowania autorów publikacji jest problem oczekiwanych kompetencji oraz cech osobowych kierownika projektów (Liikamaa, 2015; Grzesik, Piwowar-Sulej, 2018; Müller, Turner, 2016; Savelsbergh i in., 2016; Chen i in., 2019).

Podstawowym celem opracowania jest zbadanie na podstawie badań empirycznych postrzegania natężenia cech typowego menedżera projektów oraz poziomu kompetencji osób zaangażowanych w projekty, tj. menedżera projektów, menedżera portfela projektowego oraz zespołu projektowego.
Przegląd Organizacji, Nr 8 (955), 2019, ss. 41-49

www.przegladorganizacji.pl CTowarzystwo Naukowe Organizacji i Kierownictwa (TNOiK)

Realizacja tak postawionego celu została przeprowadzona poprzez dokonanie krytycznego przeglądu (eksploracja) dorobku piśmienniczego dotyczącego kompetencji z zakresu zarządzania projektami oraz zarządzania zasobami ludzkimi, jak również identyfikację, klasyfikację oraz eksplikację badanych zjawisk, a następnie ich empiryczną weryfikację na grupie pracowników polskich przedsiębiorstw, zaangażowanych zawodowo w realizację projektów.

\section{Kompetencje uczestników projektu w świetle literatury przedmiotu}

iteratura przedmiotu podaje wiele perspektyw i sposobów definiowania kompetencji. Sam termin „kompetencja" bywa wykorzystywany zarówno w odniesieniu do organizacji, jednostki organizacyjnej, zespołu projektowego, stanowiska pracy, jak również pracowników (zarówno kierowników, jak i pozostałych) (Oleksyn, 2008, s. 96). 
A. Stoof i inni (2002) wyodrębnili dwa odmienne sposoby rozpatrywania problematyki kompetencji. Pierwsze ujęcie bazuje na obiektywistycznym dążeniu do sformułowania jednej, uniwersalnej definicji kompetencji. Autorzy tego nurtu badawczego - m.in. Boyatzis (1982) oraz M. Armstrong (2005) - koncertowali swoje badania na określaniu składowych kompetencji. R. Boyatzis (1982, s. 18) zaproponował definicję kompetencji jako „potencjału istniejącego w człowieku, prowadzącego do takiego jego zachowania, które przyczynia się do zaspokojenia wymagań na danym stanowisku pracy w ramach parametrów otoczenia organizacji, co z kolei skutkuje pożądanymi wynikami”. Autor ten wyróżnił również trzy następujące składowe kompetencji: 1) motywy i cechy osobowości, 2) postrzeganie własnej osoby i jej rola społeczna, oraz 3) umiejętności (Wood, Payne, 2006, s. 38). Krytycy tego podejścia podkreślają, że jednolite ujęcie teoretyczne kompetencji nie jest możliwe ze względu na odmienność perspektyw i paradygmatów naukowych, grę interesów oraz kulturową arbitralność (Le Deist, Winterton, 2005).

Drugi, konstruktywistyczny sposób definiowania kompetencji akcentuje rolę uwarunkowań kontekstowych oraz zakłada dynamiczną naturę oraz strukturę kompetencji (Stoof i in., 2002, s. 347; Mirrable, 1997; Parry, 1996). W ramach tego nurtu badawczego proponowane są koncepcje kompetencji adresowane do różnych branż, grup zawodowych, czy też typów organizacji (Wickramasinghe, Zoyza, 2009, s. 352-353). Kompetencję definiuje się natomiast jako całokształt wiedzy, umiejętności i postaw wykorzystywanych do wykonywania złożonych zadań w określonym środowisku, spełniając tym samym standardy lub kryteria sukcesu wymagane przez to środowisko (de Kraker i in., 2007).

Na gruncie drugiego z opisanych podejść prowadzone są badania nad modelami kompetencji specyficznymi dla uczestników zespołów projektowych. Przyjmuje się, że zespół projektowy to ograniczona grupa osób o wzajemnie uzupełniających się umiejętnościach i wspólnym podejściu do pracy, zaangażowanych $\mathrm{w}$ działania zorientowane na osiągnięcie wspólnego celu głównego oraz powiązanych z nim celów szczegółowych (Katzenbach, Smith, 2001, s. 55). Szczególną rolę w funkcjonowaniu zespołu projektowego odgrywa kierownik projektu, którego głównym zadaniem jest zrealizowanie projektu i zapewnienie dostarczenia jego produktów, zgodnie z założeniami (Trocki, 2012, s. 122). Skuteczne wypełnianie funkcji kierownika projektu wymaga zarówno odpowiednich kompetencji, jak i cech osobowościowych. Analiza profilu kompetencyjnego kierownika projektu najczęściej bazuje na klasycznej triadzie umiejętności kierowniczych spopularyzowanej przez R. Katza (1974), wyróżniającej umiejętności koncepcyjne, społeczne oraz techniczne. W odniesieniu do roli kierownika projektów, szczególnie podkreśla się rangę umiejętności społecznych oraz technicznych (np. znajomość metodyk zarządzania projektami) (Musioł-Urbańczyk, 2010, s. 104; Król, 2017, s. 48). Mniejsza waga jest natomiast przypisywana umiejętnościom koncepcyjnym kierowników projektów, jednakże rola tej grupy umiejętności jest większa dla menedżerów portfela projektów, co związane jest $\mathrm{z}$ wykorzystaniem portfela projektów jako narzędzia tworzenia i wdrażania strategii organizacji (Blomquist, Müller, 2004).

Podobne spojrzenia na kompetencje uczestników projektów oferuje model kompetencji International Project Management Association (IPMA Individual Competence Baseline - ICB4), obejmujący 29 kompetencji podzielonych na trzy grupy: kompetencji technicznych (obszar „Praktyka”), kompetencji behawioralnych (obszar „Ludzie”) oraz kompetencji kontekstowych (obszar „Perspektywa”) (IPMA, 2015).

Biorąc pod uwagę powyższe propozycje, wyróżniono na potrzeby niniejszego opracowania następujące grupy kompetencji kierowników projektu (Wachowiak i in., 2004, s. 28; Kerzner, 2006, s. 149-151; Musioł-Urbańczyk, 2010; Springer, 2013; Müller, Turner, 2016; IPMA, 2015; Dziekoński, 2017):

- kompetencje techniczne, pozwalające zrozumieć naturę projektu i realizować specyficzne zadania projektowe,

- kompetencje interpersonalne, umożliwiające nawiązywanie i utrzymywanie kontaktów między ludźmi reprezentującymi różne zawody i jednostki organizacyjne,

- kompetencje diagnostyczne i analityczne, umożliwiające właściwe rozpoznanie problemów,

- kompetencje koncepcyjne, pozwalające na twórcze rozwiązywanie problemów pojawiających się podczas realizacji projektów,

- kompetencje organizacyjne, pozwalające na zaprojektowanie i wdrożenie systemu organizacyjnego umożliwiającego realizację zadań projektowych,

- kompetencje menedżerskie, przejawiające się przedsiębiorczym wykorzystaniem projektów w procesie zarządzania organizacją,

- kompetencje polityczne, umożliwiające skuteczne wywieranie wpływu na środowisko projektów.

W uzupełnieniu modeli kompetencyjnych kierownika projektu literatura tematu oferuje również zestawienia pożądanych cech osobowych. Na potrzeby niniejszego opracowania przyjęto następujący zestaw oczekiwanych cech osobowych kierownika projektu (Keeling, 2000, s. 7; Kerzner, 2006, s. 149-151; Maqbool i in., 2017; Grzesik, Piwowar-Sulej, 2018, s. 42):

- inteligencja i niezależność myślenia,

- energia i konsekwencja w działaniu,

- dążenie do ciągłego doskonalenia,

- aktywność w działaniu, a nie tylko reagowanie na zaistniałe sytuacje,

- respektowanie kompetencji i wiedzy oraz odmiennego punktu widzenia osób, z którymi współpracuje,

- chęć pomagania innym w osiąganiu indywidualnych celów,

- poczucie ograniczoności własnej wiedzy,

- otwartość na niestandardowe metody pracy,

- niezależność w ocenie faktów,

- zdolność całościowego postrzegania złożonych sytuacji. Powyższe zestawienia kompetencji oraz cech osobowych kierownika projektów stanowią punkt wyjścia dla przeprowadzenia badań empirycznych, których wyniki zaprezentowano w kolejnym punkcie opracowania. Dla lepszego zrozumienia natury kompetencji kierownika projektów postanowiono zweryfikować poziom wyróżnionych 
grup kompetencji również dla zespołu projektowego oraz dla menedżerów portfela projektów.

\section{Metoda badawcza}

$\mathbf{P}$ odstawowym celem opracowania jest zbadanie na podstawie badań empirycznych postrzeganego poziomu cech typowego menedżera projektów oraz postrzeganego poziomu kompetencji osób zaangażowanych w projekty, tj. menedżera projektów, menedżera portfela projektowego oraz zespołu projektowego, $\mathrm{z}$ uwzględnieniem różnic ze względu na płeć, wiek i staż pracy respondentów oraz sektor funkcjonowania ich organizacji. Źródłem oceny są wyniki badań empirycznych zrealizowanych w latach 2016-20181. Zakresy badań empirycznych obejmowały osoby deklarujące zawodowe zaangażowanie w projekty (podmiotowy), uwarunkowania związane $\mathrm{z}$ zarządzaniem projektami $\mathrm{w}$ organizacjach (przedmiotowy), województwo wielkopolskie (przestrzenny) oraz lata 2016-2018 (czasowy). Wielkość próby badawczej wyniosła 384 obserwacje, natomiast dobór próby miał charakter celowy - kryterium doboru była deklaracja respondenta dotycząca pracy zawodowej w projektach.

Pomiaru postrzeganych poziomów cech oraz kompetencji menedżerów projektów dokonano na skalach Likerta, na których, w przypadku cech osobowych menedżera projektów, posłużono się kategoriami: 1. niesatysfakcjonujący, 2. niski, 3. nie wiem (trudno powiedzieć), 4. zadowalający i 5. wyróżniający, wzorowy, natomiast w ocenie poziomu kompetencji posłużono się sformułowaniami: 1. bardzo niski, 2. niski, 3. nie wiem (trudno powiedzieć), 4. wysoki i 5. bardzo wysoki.

Do identyfikacji różnic ze względu na wybrane charakterystyki wykorzystano test $\mathrm{t}$ dla grup niezależnych ${ }^{2}$ oraz metodę jednoczynnikowej ANOVY. Test $\mathrm{t}$ wykorzystano przy podziale badanej zbiorowości na dwa zbiory - tj. kobiet $(\mathrm{K})$ i mężczyzn (M) oraz wiek respondentów do 35 lat $(\leq 35)$ i powyżej 35 lat (>35). Metoda jednoczynnikowej ANOVY zastosowana została przy podziale badanej zbiorowości na więcej niż dwa zbiory - tj. staż pracy do 1 roku $(<1)$, powyżej 1 roku, do 5 lat (1-5) i powyżej 5 lat $(5>)$ oraz sektory: usług (U), produkcji (P), handlu (H) i IT (IT). Struktura próby badawczej zaprezentowana została na rysunku 1.

Ocena cech osobowych typowego menedżera projektów w organizacji ograniczona została do następujących elementów: 1. inteligencji i niezależności myślenia, 2. energii i konsekwencji w działaniu, 3. dążenia do ciągłego doskonalenia, 4. aktywności w działaniu, a nie tylko reagowaniu na zaistniałe sytuacje, 5 . respektowania kompetencji i wiedzy oraz odmiennego punktu widzenia współpracowników, 6. chęci pomagania innym $\mathrm{w}$ osiąganiu indywidualnych celów, 7. poczucia ograniczoności własnej wiedzy, 8. otwartości na niestandardowe metody pracy, 9. niezależności w ocenie faktów oraz 10. zdolności całościowego postrzegania złożonych sytuacji.

\section{Wyniki badań}

U zyskane wyniki (tab. 1 i 2) pozwalają na hierarchizację cech osobowych badanych menedżerów od wyróżniających do niezadowalających. Badani najwyżej ocenili: 1. inteligencję i niezależność myślenia $(\bar{x}=3,95)$, 2. energię i konsekwencję w działaniu $(\bar{x}=3,74)$ oraz 10 . zdolność całościowego postrzegania złożonych sytuacji $(\overline{\boldsymbol{x}}=3,55)$. $\mathrm{Z}$ kolei do cech ocenianych najniżej zaliczają się: 7. poczucie ograniczoności własnej wiedzy $(\bar{x}=3,12)$, 6. chęć pomagania innym $\mathrm{w}$ osiąganiu indywidualnych celów $(\overline{\boldsymbol{x}}=3,26)$ oraz 5. respektowanie kompetencji i wiedzy oraz odmiennego punktu widzenia współpracowników $(\bar{x}=3,38)$. Ocena pozostałych cech osobowych oscyluje wokół wartości $\bar{x}=3,50$.

W pierwszej kolejności porównano postrzegany poziom cech osobowych typowego menedżera projektów w organizacji ze względu na płeć oraz wiek respondentów (tab. 1).

Analiza powyższych wyników (tab. 1) powala na identyfikację statystycznie istotnych różnic w średnim poziomie cech osobowych typowego menedżera projektów ze względu na płeć oraz wiek respondentów. W grupach kobiet i mężczyzn natężenie badanych cech osobowych menedżera projektów ocenione zostało podobnie - wyjątkiem jest 5. respektowanie kompetencji i wiedzy oraz odmiennego punktu widzenia współpracowników, przy czym poziom jest wyższy w grupie

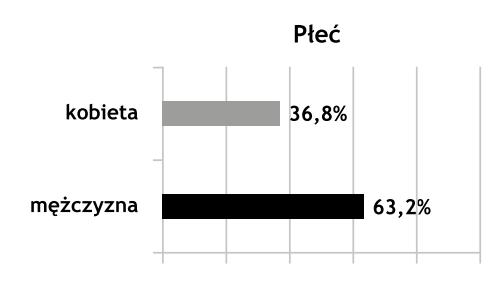

Funkcja pełniona w organizacji

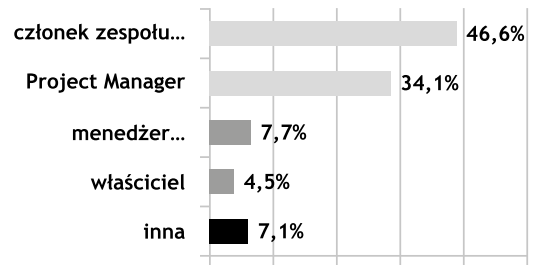

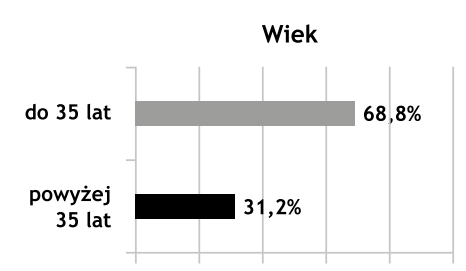

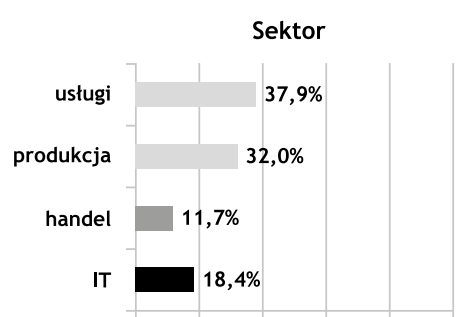

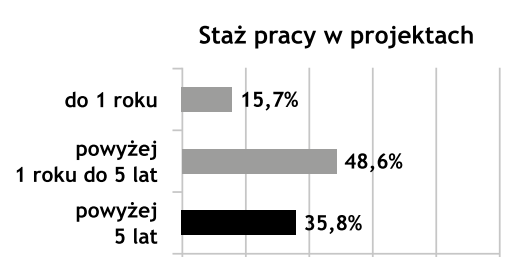

Rok badania

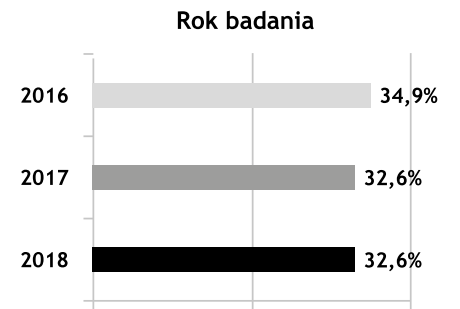

Rys. 1. Struktura próby badawczej

Źródto: opracowanie własne 
Tabela 1. Porównanie postrzeganego poziomu cech osobowych typowego menedżera projektów w organizacji ze względu na płeć oraz wiek respondentów

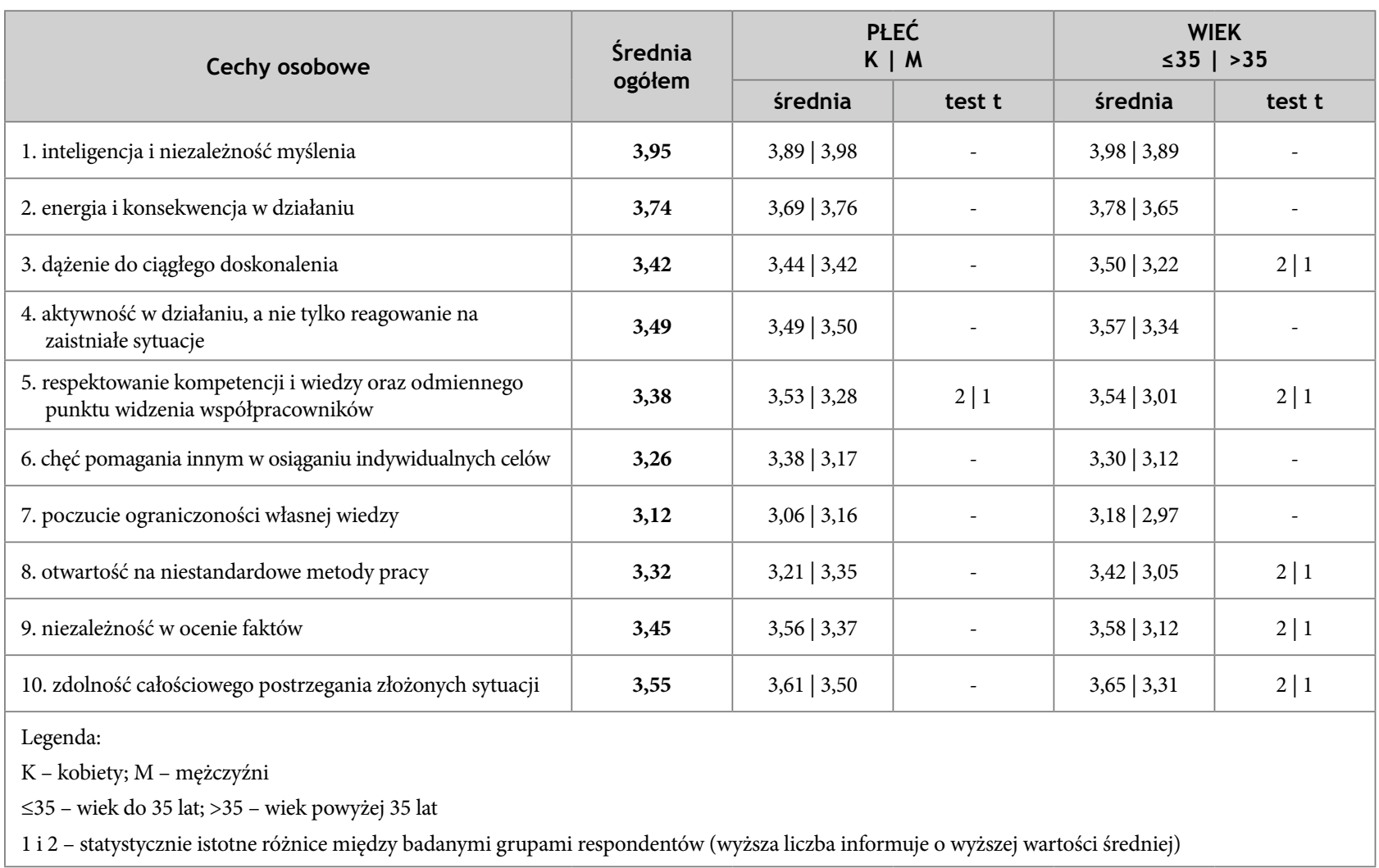

Źródto: opracowanie własne

Tabela 2. Porównanie postrzeganego poziomu cech osobowych typowego menedżera projektów w organizacji ze względu na staż pracy respondentów oraz sektor

\begin{tabular}{|c|c|c|c|c|c|}
\hline \multirow{2}{*}{ Cechy osobowe } & \multirow{2}{*}{$\begin{array}{l}\text { Średnia } \\
\text { ogółem }\end{array}$} & \multicolumn{2}{|c|}{$\begin{array}{l}\text { STAŻ PRACY } \\
<1|1-5| 5>\end{array}$} & \multicolumn{2}{|c|}{$\begin{array}{c}\text { SEKTOR } \\
\mathrm{U}|\mathrm{P}| \mathrm{H} \mid \mathrm{IT}\end{array}$} \\
\hline & & średnia & ANOVA & średnia & ANOVA \\
\hline 1. inteligencja i niezależność myślenia & 3,95 & $4,03|3,98| 3,88$ & - & $3,89|3,83| 3,80 \mid 4,35$ & $1|1| 1 \mid 2$ \\
\hline 2. energia i konsekwencja w działaniu & 3,74 & $3,87|3,67| 3,77$ & - & $3,70|3,64| 3,48 \mid 4,03$ & $1|1| 1 \mid 2$ \\
\hline 3. dążenie do ciągłego doskonalenia & 3,42 & $3,33|3,47| 3,38$ & - & $3,40|3,42| 3,23 \mid 3,52$ & - \\
\hline $\begin{array}{l}\text { 4. aktywność w działaniu, a nie tylko reagowanie na } \\
\text { zaistniałe sytuacje }\end{array}$ & 3,49 & $3,80|3,33| 3,57$ & $2|1| 2$ & $3,35|3,62| 3,20 \mid 3,78$ & $1|2| 1 \mid 2$ \\
\hline $\begin{array}{l}\text { 5. respektowanie kompetencji i wiedzy oraz odmiennego } \\
\text { punktu widzenia współpracowników }\end{array}$ & 3,38 & $3,70|3,38| 3,24$ & $2|1| 1$ & $3,32|3,27| 3,45 \mid 3,57$ & - \\
\hline $\begin{array}{l}\text { 6. chęć pomagania innym w osiąganiu indywidualnych } \\
\text { celów }\end{array}$ & 3,26 & $3,47|3,17| 3,28$ & - & $3,30|2,99| 3,11 \mid 3,61$ & $1|1| 1 \mid 2$ \\
\hline 7. poczucie ograniczoności własnej wiedzy & 3,12 & $3,08|3,12| 3,16$ & - & $3,09|3,02| 2,95 \mid 3,49$ & $1|1| 1 \mid 2$ \\
\hline 8. otwartość na niestandardowe metody pracy & 3,32 & $3,52|3,29| 3,25$ & - & $3,25|3,06| 3,52 \mid 3,62$ & $1|1| 2 \mid 2$ \\
\hline 9. niezależność w ocenie faktów & 3,45 & $3,52|3,47| 3,39$ & - & $3,43|3,24| 3,59 \mid 3,65$ & - \\
\hline 10. zdolność całościowego postrzegania złożonych sytuacji & 3,55 & $3,75|3,47| 3,55$ & - & $3,65|3,27| 3,68 \mid 3,65$ & $2|1| 2 \mid 2$ \\
\hline \multicolumn{6}{|c|}{$\begin{array}{l}\text { Legenda: } \\
<1 \text { - staż pracy do } 1 \text { roku; } 1-5 \text { - staż pracy pow. } 1 \text { roku, do } 5 \text { lat; } 5>\text { - staż pracy powyżej } 5 \text { lat } \\
\mathrm{U} \text { - usługi; } \mathrm{P} \text { - produkcja; } \mathrm{H} \text { - handel; IT - sektor IT }\end{array}$} \\
\hline
\end{tabular}

Źródło: opracowanie własne 
kobiet. Różnice ze względu na wiek badanych respondentów są zdecydowanie częstsze, przy czym zaobserwować można prawidłowość, zgodnie z którą postrzegany poziom cech osobowych typowego menedżera projektów jest niższy w grupie respondentów powyżej 35 roku życia, co świadczyć może o występowaniu efektu rutyny zawodowej w tym przypadku.

Następnie dokonano porównania postrzeganego poziomu cech osobowych typowego menedżera w organizacji ze względu na staż pracy respondentów oraz sektor, w którym funkcjonuje ich organizacja (tab. 2).

Uzyskane wyniki (tab. 2) pozwalają na identyfikację statystycznie istotnych różnic $\mathrm{w}$ średnim poziomie cech osobowych typowego menedżera projektów ze względu na staż pracy respondentów (dwie różnice) oraz sektor funkcjonowania organizacji (osiem różnic). W przypadku stażu pracy ocena badanych cech osobowych jest generalnie podobna - wyjątkiem jest 4. aktywność w działaniu, a nie tylko reagowanie na zaistniałe sytuacje, czego ranga jest najniższa w grupie osób ze stażem pracy powyżej 1 roku do 5 lat oraz 5. respektowanie kompetencji i wiedzy oraz odmiennego punktu widzenia współpracowników, przy czym nasilenie jest najwyższe w grupie osób o najkrótszym stażu zawodowym. Wskazuje to na występowanie analogii w porównaniu do oceny poziomu tej cechy ze względu na wiek respondentów. Z kolei analiza wyników uzyskanych w poszczególnych sektorach pozwala na wskazanie sektora IT, w którym natężenie cech osobowych typowego menedżera projektów jest każdorazowo wyższe lub przynajmniej równe w porównaniu do pozostałych sektorów, tj. usług, produkcji i handlu. Świadczyć to może o występowaniu szczególnych wyzwań zawodowych związanych z realizacją projektów w sektorze IT oraz wskazuje na konieczność doboru menedżerów projektów w organizacji charakteryzujących się ponadprzeciętnym poziomem badanych cech osobowych.

Ocena kompetencji zespołów projektowych, menedżerów projektów oraz menedżerów portfelów projektowych uwzględniała kompetencje: 1. techniczne - zrozumienie istoty koniecznych do wykonania zadań, 2. interpersonalne - nawiązywanie i utrzymywanie relacji między ludźmi z różnych zawodów i jednostek organizacyjnych, 3. diagnostyczne i analityczne - umożliwiające dokonanie diagnozy problemów, 4. koncepcyjne - twórcze rozwiązywanie problemów występujących podczas realizacji projektów, 5. organizacyjne - zaprojektowanie i wdrożenie systemu umożliwiającego realizację zaplanowanych zadań, 6 . menedżerskie - w zakresie zarządzania projektami oraz 7. polityczne - oddziaływanie na środowisko projektów. Do kompetencji najwyżej ocenianych respondenci zaliczyli (tab. 3-6):

- w zespole projektowym w szczególności kompetencje

1. techniczne $(\bar{x}=4,04)$,

- $\mathrm{u}$ menedżera projektu kompetencje 6 . menedżerskie $(\overline{\boldsymbol{x}}=3,88)$ oraz 2 . interpersonalne $(\overline{\boldsymbol{x}}=3,78)$,

- w przypadku menedżera portfela projektów kompetencje 6 . menedżerskie $(\bar{x}=3,54)$ i 7 . polityczne $(\bar{x}=3,52)$.

$\mathrm{Z}$ kolei do zbiorów kompetencji o najniższym poziomie respondenci zaliczyli:

- $\mathrm{w}$ zespole projektowym kompetencje 7. polityczne $(\overline{\boldsymbol{x}}=2,70)$ i 6 . menedżerskie $(\overline{\boldsymbol{x}}=2,93)$,

- w przypadku menedżera projektu przede wszystkim kompetencje 7. polityczne $(\overline{\boldsymbol{x}}=3,35)$,

- u menedżera portfela projektów zwłaszcza kompetencje 1 . techniczne $(\bar{x}=3,29)$.

Tabela 3. Porównanie postrzeganego poziomu kompetencji w organizacji ze względu na płeć respondentów

\begin{tabular}{|c|c|c|c|c|c|c|c|c|c|}
\hline \multirow{2}{*}{ Kompetencje } & \multirow{9}{*}{ 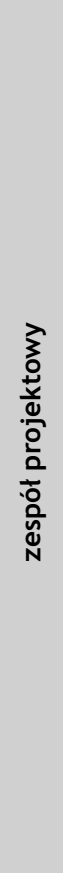 } & \multicolumn{2}{|c|}{$\begin{array}{l}\text { PŁEĆ } \\
K \mid M\end{array}$} & \multicolumn{3}{|c|}{$\begin{array}{l}\text { PLEĆ } \\
\mathrm{K} \mid \mathrm{M}\end{array}$} & \multicolumn{3}{|c|}{$\begin{array}{l}\text { PLEĆ } \\
K \mid M\end{array}$} \\
\hline & & średnia & test $\mathrm{t}$ & \multirow{8}{*}{ 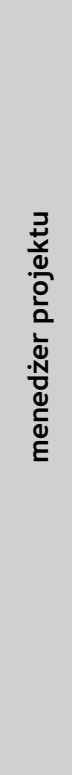 } & średnia & test $\mathrm{t}$ & \multirow{8}{*}{ 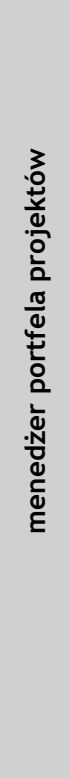 } & średnia & test $\mathrm{t}$ \\
\hline 1. techniczne & & $\begin{array}{c}\mathbf{4 , 0 4} \\
4,01 \mid 4,07\end{array}$ & - & & $\begin{array}{c}3,76 \\
3,88 \mid 3,70\end{array}$ & - & & $\begin{array}{c}3,29 \\
3,37 \mid 3,25\end{array}$ & - \\
\hline 2. interpersonalne & & $\begin{array}{c}3,44 \\
3,68 \mid 3,30\end{array}$ & $2 \mid 1$ & & $\begin{array}{c}\mathbf{3 , 7 8} \\
3,77 \mid 3,77\end{array}$ & - & & $\begin{array}{c}3,47 \\
3,53 \mid 3,43\end{array}$ & - \\
\hline $\begin{array}{l}\text { 3. diagnostyczne } \\
\text { i analityczne }\end{array}$ & & $\begin{array}{c}\mathbf{3 , 5 5} \\
3,46 \mid 3,63\end{array}$ & - & & $\begin{array}{c}3,71 \\
3,54 \mid 3,79\end{array}$ & $1 \mid 2$ & & $\begin{array}{c}3,44 \\
3,42 \mid 3,44\end{array}$ & - \\
\hline 4. koncepcyjne & & $\begin{array}{c}3,47 \\
3,59 \mid 3,40\end{array}$ & - & & $\begin{array}{c}3,73 \\
3,73 \mid 3,73\end{array}$ & - & & $\begin{array}{c}3,46 \\
3,43 \mid 3,47\end{array}$ & - \\
\hline 5. organizacyjne & & $\begin{array}{c}3,22 \\
3,52 \mid 3,04\end{array}$ & $2 \mid 1$ & & $\begin{array}{c}3,77 \\
3,75 \mid 3,76\end{array}$ & - & & $\begin{array}{c}3,40 \\
3,47 \mid 3,35\end{array}$ & - \\
\hline 6. menedżerskie & & $\begin{array}{c}\mathbf{2 , 9 3} \\
3,20 \mid 2,77\end{array}$ & $2 \mid 1$ & & $\begin{array}{c}\mathbf{3 , 8 8} \\
3,86 \mid 3,88\end{array}$ & - & & $\begin{array}{c}\mathbf{3 , 5 4} \\
3,53 \mid 3,55\end{array}$ & - \\
\hline 7. polityczne & & $\begin{array}{c}\mathbf{2 , 7 0} \\
2,93 \mid 2,58\end{array}$ & $2 \mid 1$ & & $\begin{array}{c}3,35 \\
3,46 \mid 3,29\end{array}$ & - & & $\begin{array}{c}3,52 \\
3,56 \mid 3,61\end{array}$ & $1 \mid 2$ \\
\hline
\end{tabular}

Źródło: opracowanie własne 
Następnie porównano postrzegany poziom kompetencji w organizacji ze względu na płeć respondentów (tab. 3).

Uzyskane wyniki (tab. 3) pozwalają na identyfikację statystycznie istotnych różnic $\mathrm{w}$ średnim poziomie kompetencji w zespole projektowym, u menedżera projektu oraz menedżera portfela projektów ze względu na płeć respondentów. Najwięcej różnic zidentyfikowano w zespole projektowym - występują w przypadku kompetencji 2. interpersonalnych, 5. organizacyjnych, 6. menedżerskich oraz 7. politycznych i zostały każdorazowo wyżej ocenione przez grupę kobiet. W przypadku menedżera projektów zwrócić należy uwagę na kompetencje 3. diagnostyczne i analityczne, których rola jest wyższa w grupie mężczyzn, natomiast u menedżera portfela projektów mężczyźni wyżej ocenili poziom kompetencji 7. politycznych.

Kolejnym krokiem postępowania badawczego było porównanie postrzeganego poziomu kompetencji ze względu na wiek respondentów (tab. 4).

Porównanie poziomu kompetencji ze względu na wiek respondentów (tab. 4) wskazuje na obszary kompetencji, których rola zmienia się $\mathrm{w}$ badanych grupach respondentów - osób do 35 roku życia oraz osób w wieku powyżej 35 lat. Analiza wyników pozwala na wskazanie prawidłowości, zgodnie z którą rola kompetencji jest oceniana wyżej przez osoby w wieku pow. 35 lat. Dotyczy to zespołu projektowego, zwłaszcza kompetencji 2. interpersonalnych, 3. diagnostycznych i analitycznych, 4. koncepcyjnych, 5. organizacyjnych, 6. menedżerskich i 7. politycznych, menedżera projektu i jego kompetencji 2. interpersonalnych oraz menedżera portfela projektów i jego kompetencji 2. interpersonalnych oraz 3. diagnostycznych i analitycznych. Uzyskane wyniki, podobnie jak w przypadku cech osobowych typowego menedżera projektu, świadczyć mogą o występowaniu efektu rutyny zawodowej.

Porównanie postrzeganego poziomu kompetencji w organizacji ze względu na staż pracy respondentów zaprezentowano w tabeli 5 .

Uzyskane wyniki (tab. 5) wskazują na występowanie relatywnie częstych różnic $\mathrm{w}$ ocenie natężenia kompetencji ze względu na staż pracy respondentów, zwłaszcza w zespołach projektowych. Rola kompetencji 1. technicznych w zespole projektowym i u menedżera projektu jest najwyższa w grupie osób ze stażem pracy powyżej 1 roku, podobnie ranga kompetencji 2 . interpersonalnych menedżera projektu. Rola kompetencji 3. diagnostycznych i analitycznych zespołu projektowego rośnie w grupie osób o najdłuższym stażu pracy (pow. 5 lat), natomiast poziom kompetencji 4. koncepcyjnych menedżera portfela projektów rośnie w grupach ze stażem powyżej 1 roku. W przypadku kompetencji 5. organizacyjnych nie zidentyfikowano statystycznie istotnych różnic. Z kolei rola kompetencji 6. menedżerskich i 7. politycznych jest odmiennie postrzegana, zwłaszcza w przypadku zespołu projektowego i menedżera portfela projektów - ich średnie natężenie jest niższe $\mathrm{w}$ zespole projektowym oraz wyższe u menedżera portfela projektów w grupach o dłuższym stażu pracy. Uzyskane wyniki potwierdzają występowanie rosnącego natężenia kompetencji o charakterze koncepcyjnym na stanowiskach kierowniczych oraz dużą rolę kompetencji o charakterze technicznym w zespołach projektowych.

Ostatnim krokiem postępowania badawczego było porównanie postrzeganego poziomu kompetencji w organizacji z uwzględnieniem różnic sektorowych (tab. 6).

Tabela 4. Porównanie postrzeganego poziomu kompetencji w organizacji ze względu na wiek respondentów

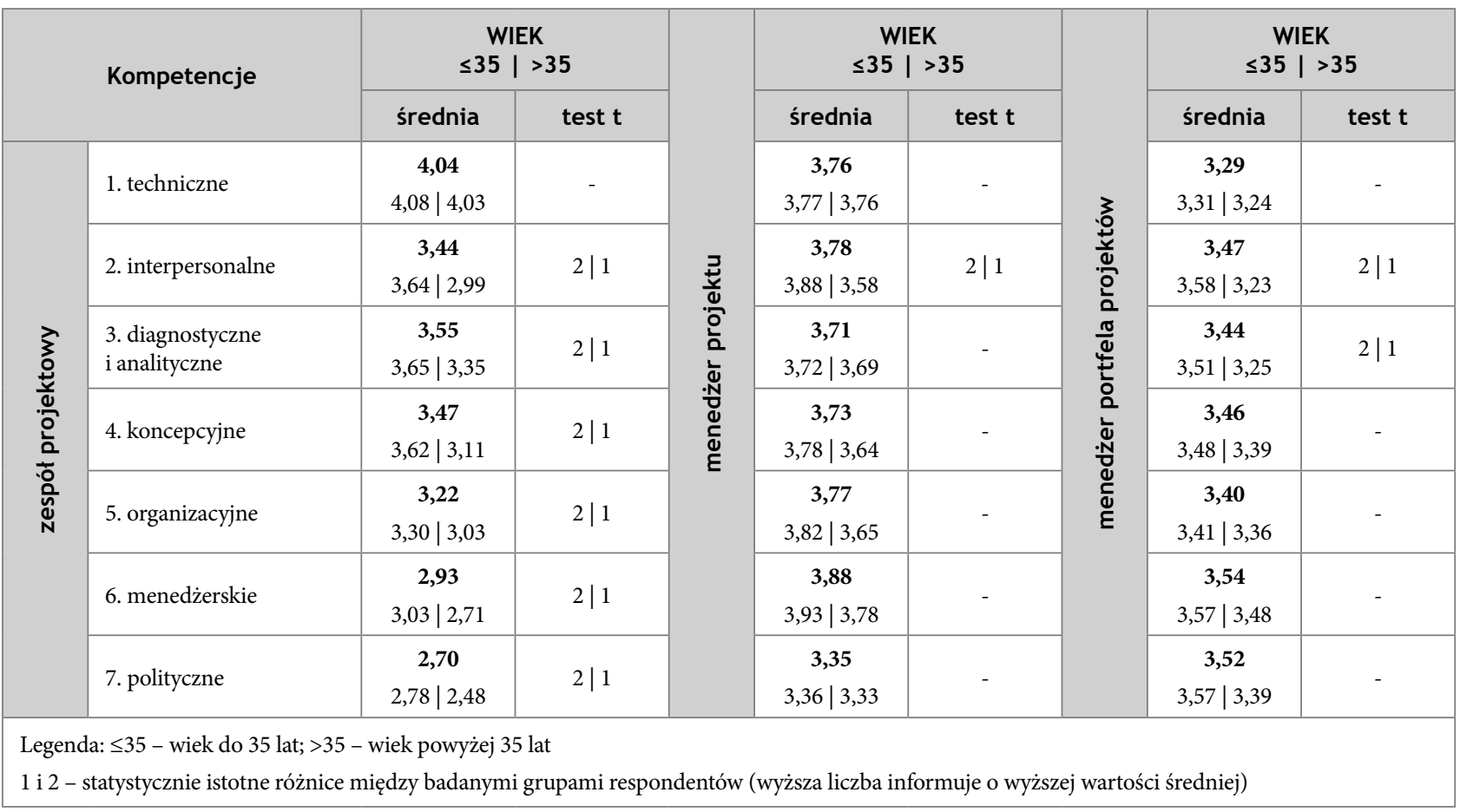

Źródło: opracowanie własne 
Tabela 5. Porównanie postrzeganego poziomu kompetencji w organizacji ze względu na staż pracy respondentów

\begin{tabular}{|c|c|c|c|c|c|c|c|c|c|}
\hline & \multirow{2}{*}{$\begin{array}{l}\text { Kompetencje } \\
\text { średnia }\end{array}$} & \multicolumn{2}{|c|}{$\begin{array}{l}\text { STAŻ PRACY } \\
<1|1-5| 5>\end{array}$} & \multirow{9}{*}{ 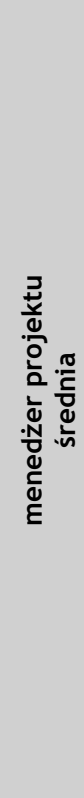 } & \multicolumn{2}{|c|}{$\begin{array}{l}\text { STAŻ PRACY } \\
<1|1-5| 5>\end{array}$} & \multirow{9}{*}{ 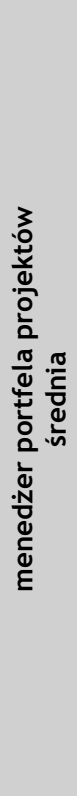 } & \multicolumn{2}{|c|}{$\begin{array}{l}\text { STAŻ PRACY } \\
<1|1-5| 5>\end{array}$} \\
\hline & & średnia & ANOVA & & średnia & ANOVA & & średnia & ANOVA \\
\hline \multirow{7}{*}{ 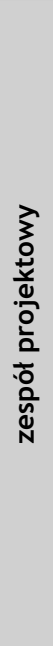 } & 1. techniczne & $\begin{array}{c}\mathbf{4 , 0 4} \\
3,68|4,12| 4,10\end{array}$ & $1|2| 2$ & & $\begin{array}{c}\mathbf{3 , 7 6} \\
3,37|3,89| 3,76\end{array}$ & $1|2| 2$ & & $\begin{array}{c}\mathbf{3 , 2 9} \\
3,23|3,34| 3,26\end{array}$ & - \\
\hline & 2. interpersonalne & $\begin{array}{c}\mathbf{3 , 4 4} \\
3,28|3,61| 3,28\end{array}$ & $1|2| 1$ & & $\begin{array}{c}\mathbf{3 , 7 8} \\
3,30|3,88| 3,84\end{array}$ & $1|2| 2$ & & $\begin{array}{c}\mathbf{3 , 4 7} \\
3,38|3,47| 3,53\end{array}$ & - \\
\hline & $\begin{array}{l}\text { 3. diagnostyczne } \\
\text { i analityczne }\end{array}$ & $\begin{array}{c}\mathbf{3 , 5 5} \\
3,32|3,51| 3,72\end{array}$ & $1|1| 2$ & & $\begin{array}{c}\mathbf{3 , 7 1} \\
3,47|3,74| 3,76\end{array}$ & - & & $\begin{array}{c}\mathbf{3 , 4 4} \\
3,25|3,55| 3,37\end{array}$ & - \\
\hline & 4. koncepcyjne & $\begin{array}{c}\mathbf{3 , 4 7} \\
3,25|3,55| 3,45\end{array}$ & - & & $\begin{array}{c}\mathbf{3 , 7 3} \\
3,60|3,74| 3,77\end{array}$ & - & & $\begin{array}{c}\mathbf{3 , 4 6} \\
3,25|3,42| 3,59\end{array}$ & $1|2| 2$ \\
\hline & 5. organizacyjne & $\begin{array}{c}\mathbf{3 , 2 2} \\
3,30|3,32| 3,06\end{array}$ & - & & $\begin{array}{c}3,77 \\
3,63|3,81| 3,76\end{array}$ & - & & $\begin{array}{c}\mathbf{3 , 4 0} \\
3,23|3,34| 3,55\end{array}$ & - \\
\hline & 6. menedżerskie & $\begin{array}{c}\mathbf{2 , 9 3} \\
3,25|2,97| 2,74\end{array}$ & $2|1| 1$ & & $\begin{array}{c}\mathbf{3 , 8 8} \\
3,77|3,87| 3,93\end{array}$ & - & & $\begin{array}{c}\mathbf{3 , 5 4} \\
3,30|3,47| 3,76\end{array}$ & $1|1| 2$ \\
\hline & 7. polityczne & \begin{tabular}{c|c}
$\mathbf{2 , 7 0}$ \\
$2,95|2,78| 2,49$
\end{tabular} & $2|2| 1$ & & $\begin{array}{c}\mathbf{3 , 3 5} \\
3,30|3,31| 3,42\end{array}$ & - & & $\begin{array}{c}\mathbf{3 , 5 2} \\
3,23|3,50| 3,68\end{array}$ & $1|2| 2$ \\
\hline
\end{tabular}

Legenda: $<1$ - staż pracy do 1 roku; 1-5 - staż pracy pow. 1 roku, do 5 lat; $>5$ - staż pracy powyżej 5 lat

1 i 2 - statystycznie istotne różnice między badanymi grupami respondentów (wyższa liczba informuje o wyższej wartości średniej)

Źródło: opracowanie własne

Tabela 6. Porównanie postrzeganego poziomu kompetencji w organizacji ze względu na sektor

\begin{tabular}{|c|c|c|c|c|c|c|c|c|c|}
\hline & \multirow[t]{2}{*}{ Kompetencje } & \multicolumn{2}{|c|}{$\begin{array}{c}\text { SEKTOR } \\
\mathrm{U} \mid \mathrm{P} \\
\mathrm{H} \mid \mathrm{IT}\end{array}$} & \multirow{9}{*}{ 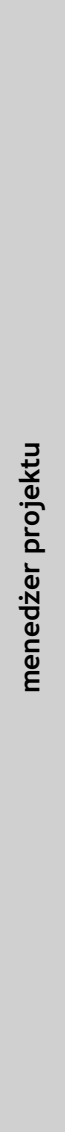 } & \multicolumn{2}{|c|}{$\begin{array}{c}\text { SEKTOR } \\
\mathrm{U} \mid \mathrm{P} \\
\mathrm{H} \mid \mathrm{IT}\end{array}$} & \multirow{9}{*}{ 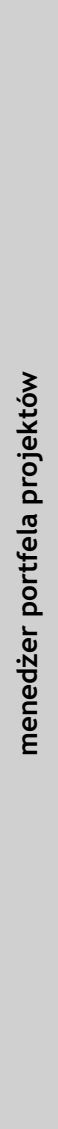 } & \multicolumn{2}{|c|}{$\begin{array}{c}\text { SEKTOR } \\
\mathrm{U} \mid \mathrm{P} \\
\mathrm{H} \mid \mathrm{IT}\end{array}$} \\
\hline & & średnia & ANOVA & & średnia & ANOVA & & średnia & ANOVA \\
\hline \multirow{7}{*}{ 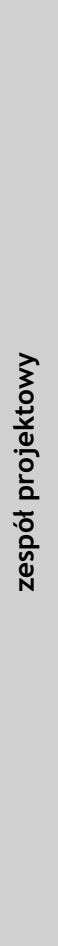 } & 1. techniczne & $\begin{array}{c}\mathbf{4 , 0 4} \\
3,99 \mid 4,03 \\
3,89 \mid 4,23\end{array}$ & - & & $\begin{array}{c}3,76 \\
3,71 \mid 3,83 \\
3,82 \mid 3,71\end{array}$ & - & & $\begin{array}{c}3,29 \\
3,30 \mid 3,28 \\
3,45 \mid 3,17\end{array}$ & - \\
\hline & 2. interpersonalne & $\begin{array}{c}3,44 \\
3,56 \mid 3,28 \\
3,27 \mid 3,51\end{array}$ & - & & \begin{tabular}{c|c}
3,78 \\
$3,80 \mid$ & 3,65 \\
3,68 & 3,94
\end{tabular} & - & & $\begin{array}{c}3,47 \\
3,48 \mid 3,31 \\
3,64 \mid 3,62\end{array}$ & - \\
\hline & $\begin{array}{l}\text { 3. diagnostyczne } \\
\text { i analityczne }\end{array}$ & $\begin{array}{c}3,55 \\
3,53 \mid 3,47 \\
3,68 \mid 3,72\end{array}$ & - & & $\begin{array}{c}3,71 \\
3,56 \mid 3,79 \\
3,36 \mid 4,01\end{array}$ & \begin{tabular}{l|l}
$1 \mid$ & 2 \\
1 & 3
\end{tabular} & & $\begin{array}{c}3,44 \\
3,35 \mid 3,57 \\
3,20 \mid 3,51\end{array}$ & - \\
\hline & 4. koncepcyjne & $\begin{array}{c}3,47 \\
3,56 \mid 3,25 \\
3,48 \mid 3,61\end{array}$ & - & & $\begin{array}{c}3,73 \\
3,70 \mid 3,68 \\
3,77 \mid 3,87\end{array}$ & - & & $\begin{array}{c}3,46 \\
3,46 \mid 3,37 \\
3,34 \mid 3,67\end{array}$ & - \\
\hline & 5. organizacyjne & $\begin{array}{c}\mathbf{3 , 2 2} \\
3,32 \mid 2,93 \\
3,55 \mid 3,33\end{array}$ & \begin{tabular}{l|l}
2 & 1 \\
2 & 2
\end{tabular} & & $\begin{array}{c}3,77 \\
3,62 \mid 3,67 \\
4,00 \mid 4,04\end{array}$ & \begin{tabular}{l|l}
$1 \mid$ & 1 \\
2 & 2
\end{tabular} & & $\begin{array}{c}\mathbf{3 , 4 0} \\
3,40 \mid 3,13 \\
3,23 \mid 3,94\end{array}$ & \begin{tabular}{l|l}
$1 \mid$ & 1 \\
$1 \mid$ & 2
\end{tabular} \\
\hline & 6. menedżerskie & $\begin{array}{c}2,93 \\
2,97 \mid 2,81 \\
3,11 \mid 2,83\end{array}$ & - & & $\begin{array}{c}\mathbf{3 , 8 8} \\
3,86 \mid 3,78 \\
3,89 \mid 4,07\end{array}$ & - & & $\begin{array}{c}3,54 \\
3,54 \mid 3,37 \\
3,48 \mid 3,88\end{array}$ & \begin{tabular}{l|l}
$1 \mid$ & 1 \\
$1 \mid$ & 2
\end{tabular} \\
\hline & 7. polityczne & \begin{tabular}{c|c}
2,70 \\
$2,85 \mid 2,68$ \\
$2,64 \mid 2,41$
\end{tabular} & - & & $\begin{array}{c}3,35 \\
3,54 \mid 3,13 \\
3,41 \mid 3,32\end{array}$ & - & & \begin{tabular}{c|c}
$\mathbf{3 , 5 2}$ \\
$3,58 \mid 3,36$ \\
$3,36 \mid 3,80$
\end{tabular} & \begin{tabular}{l|l}
$1 \mid$ & 1 \\
$1 \mid 2$
\end{tabular} \\
\hline
\end{tabular}

Źródto: opracowanie własne 
Uzyskane wyniki (tab. 6) pozwalają na wskazanie obszarów kompetencji, których poziom zmienia się w poszczególnych sektorach - usług, produkcji, handlu i IT. W przypadku zespołu projektowego ocena poziomu kompetencji jest porównywalna, poza kompetencjami 5. organizacyjnymi, których ranga jest niższa w sektorze produkcyjnym. Ocena kompetencji menedżera projektu jest zróżnicowana w obszarze kompetencji 3. diagnostycznych i analitycznych, których rola jest najwyższa w sektorze IT, średnia w sektorze produkcyjnym, a najniższa w sektorach usług i handlu oraz w obszarze kompetencji 5. organizacyjnych, których rola jest wyższa w sektorach IT oraz handlu. Natomiast ocena kompetencji menedżera portfela projektów, zwłaszcza w zakresie kompetencji 5. organizacyjnych, 6. menedżerskich i 7. politycznych jest najwyższa w sektorze IT. Uzyskane wyniki wskazują na sektor IT jako wyróżniający pod względem kompetencyjnym we wszystkich badanych rolach zawodowych. Wynikać to może z popularności metodyki SCRUM w realizacji projektów informatycznych, a zwłaszcza sposobu organizacji pracy zespołu deweloperskiego, który cechować powinien się samoorganizacją, ograniczeniem korzystania z zewnętrznych względem projektu zasobów ludzkich, brakiem występowania innych ról zawodowych wewnątrz zespołu oraz wspólną odpowiedzialnością - co wymusza współdziałanie we wszystkich obszarach związanych z projektowanym produktem końcowym oraz konieczność posiadania kompetencji podobnych do pozostałych członków grupy projektowej.

\section{Podsumowanie}

$\mathbf{P}$ odstawowym celem opracowania była zbadanie na podstawie badań empirycznych postrzegania poziomów cech osobowych typowego menedżera projektów, określenie poziomu kompetencji wybranych osób zaangażowanych w projekty, a także rozpoznanie różnic w cechach osobowych oraz kompetencjach ze względu na płeć, wiek, staż pracy respondentów i sektor funkcjonowania ich organizacji. W zakresie cech osobowych typowego menedżera projektów do zmiennych różnicujących najczęściej postrzegane poziomy tych cech zaliczyć należy przede wszystkim wiek oraz sektor funkcjonowania organizacji, z kolei do zmiennych różnicujących najrzadziej płeć oraz staż pracy. Uzyskane wyniki wskazują na najbardziej pożądane cechy menedżera projektów, do których respondenci zaliczyli elementy związane z kompetencjami koncepcyjnymi, tj. inteligencję i niezależność myślenia, energię i konsekwencję w działaniu oraz zdolność całościowego postrzegania złożonych sytuacji. Z kolei ocena kompetencji pozwoliła na wskazanie tych, które są najbardziej pożądane ze względu na funkcję pełnioną w projektach - w zespole projektowym respondenci wskazali przede wszystkim na kompetencje techniczne, u menedżera projektu na kompetencje menedżerskie oraz interpersonalne, z kolei w przypadku menedżera portfela projektów na kompetencje menedżerskie i polityczne.

W uzupełnieniu powyższych wniosków należy, zadaniem autorów, zwrócić uwagę na następujące trudności, ograniczenia i dylematy związane $\mathrm{z}$ badaniem, oceną oraz kształtowaniem kompetencji uczestników zespołów projektowych:
- wieloznaczność, nieostrość i ograniczona mierzalność większości kompetencji;

- złożoność kompetencji oraz powielania się kompetencji elementarnych w ramach różnych kompetencji złożonych;

- trudność określenia właściwego profilu kompetencyjnego, szczególnie w odniesieniu do kształtowania odpowiednich relacji między kompetencjami twardymi i miękkimi;

- problem granic rozwoju kompetencji związany z kosztami wydatkowanymi na kształtowanie kwalifikacji uczestników projektów, które nie zostaną odpowiednio wykorzystane w praktyce projektowej.

Należy podkreślić istotne ograniczenie szerszej interpretacji przedstawionych wyników badań ze względu na brak reprezentatywności wykorzystanej próby badawczej. Autorzy, wśród możliwych do podjęcia kierunków dalszych badań, jako szczególnie interesujące uznają analizę procesu kształtowania kompetencji menedżera projektów, jak również relacji zachodzących pomiędzy kompetencjami i cechami uczestników projektów a skutecznością zarządzania projektami różnych typów.

\section{dr Maciej Brzozowski \\ Uniwersytet Ekonomiczny w Poznaniu \\ Wydział Zarządzania \\ ORCID: 0000-0002-9651-2611 \\ e-mail: m.brzozowski@ue.poznan.pl \\ dr Paweł Bartkowiak \\ Uniwersytet Ekonomiczny w Poznaniu \\ Wydział Zarządzania \\ ORCID: 0000-0001-9330-756X \\ e-mail: pawel.bartkowiak@ue.poznan.pl}

\section{Przypisy}

1) Analiza uzyskanych wyników przeprowadzona została $z$ wykorzystaniem programu IBM Statistics ver. 21.

2) Test $t$ jest metodą oceny różnic między średnimi $w$ dwóch zbiorach - podawany w wynikach testu t poziom $\mathrm{p}$ wskazuje na prawdopodobieństwo błędu związanego z przyjęciem hipotezy o istnieniu różnic między średnimi (Wieczorkowska, Wierzbiński, 2011).

\section{Bibliografia}

[1] Armstrong M. (2005), Zarządzanie zasobami ludzkimi, Oficyna Ekonomiczna, Kraków,

[2] Blomquist T., Müller R. (2004), Program and Portfolio Managers: Analysis of Roles and Responsibilities, Paper presented at $\mathrm{PMI}^{\circledR}$ Research Conference: Innovations, Project Management Institute, Newtown Square, London.

[3] Boyatzis R. (1982), The Competent Manager: A Model for Effective Performance, John Wiley, New York.

[4] Chen T., Fu M., Liu R., Xu X., Zhou S., Liu B. (2019), How do Project Management Competencies Change within the Project Management Career Model in Large Chinese Construction Companies? „International Journal of Project Management”, Vol. 37, pp. 485-500. 
[5] De Kraker J., Lansu A., van Dam-Mieras R. (2007), Competences and Competence-based Learning for Sustainable Development, [in:] J. de Kraker, A. Lansu, R. van Dam-Mieras (eds.), Crossing Boundaries. Innovative Learning for Sustainable Development in Higher Education, Verlag für Akademische Schriften, Frankfurt am Main, pp. 103-114.

[6] Dziekoński K. (2017), Project Managers' Competencies Model for Construction Industry in Poland, „Procedia Engineering", Vol. 182, pp. 174-181.

[7] Grzesik K., Piwowar-Sulej K. (2018), Project Managers' Competencies and Leadership Styles from the Perspective of Organizations Functioning in Poland, „Journal of Entrepreneurship, Management and Innovation (JEMI)", Vol. 14, No. 3, pp. 35-60.

[8] IPMA, (2015), Wytyczne Kompetencji Indywidualnych $w$ Zarzadzaniu Projektami, Programami i Portfelami. IPMA Individual Competence Baseline ${ }^{\bullet}$ (IPMA ICB). Wersja 4.0.

[9] Katz R. (1974), Skills of an Effective Administrator, „Harvard Business Review", September, pp. 90-102.

[10] Katzenbach J., Smith D. (2001), Siła zespołów. Wplyw pracy zespołowej na efektywność organizacji, Oficyna Ekonomiczna, Kraków.

[11] Keeling R. (2000), Project Management. An International Perspective, St. Martin Press, New York.

[12] Kerzner H. (2006), Project Management. A System Approach To Planning, Scheduling And Controlling, John Wiley \& Sons, Chichester.

[13] Król M. (2017), Skuteczne zarządzanie projektami a kompetencje interpersonalne, CeDeWu, Warszawa.

[14] Le Deist F.D. Winterton J. (2005), What is Competen$c e$ ? „Human Resource Development International”, Vol. 8, No. 1, pp. 27-46.

[15] Liikamaa K. (2015), Developing a Project Manager's Competencies: A Collective View of the Most Important Competencies, „Procedia Manufacturing”, Vol. 3, pp. 681-687.

[16] Maqbool R., Sudnong Y., Manzoor N., Rashid Y. (2017), The Impact of Emotional Intelligence, Project Managers' Competencies, and Transformational Leadership on Project Success: An Empirical Perspective, „Project Management Journal", Vol. 48, No. 3, pp. 58-75.

[17] Mirabile R.J. (1997), Everything you Wanted to Know about Competency Modeling. „Training and Development”, Vol. 51, No. 8, pp. 73-77.

[18] Müller R., Turner J.R. (2016), Project-oriented Leadership. Routledge, New York.

[19] Musioł-Urbańczyk A. (2010), Kompetencje kierownika projektu i możliwości ich ksztaltowania, Wydawnictwo Politechniki Śląskiej, Gliwice.

[20] Oleksyn T. (2008), Zarzadzanie zasobami ludzkimi w organizacji. Kanony, realia, kontrowersje, Oficyna a Wolters Kluwer Business, Kraków.

[21] Parry S.B. (1996), The Quest for Competences: Competency Studies Can Help You Make HR Decision, but the Results Are Only as Good as the Study, „Training”, Vol. 33, pp. 48-56.

[22] Savelsbergh Ch., Havermans L., Storm P. (2016), Development Path of Project Managers: What and How do Project Managers Learn from Their Experiences? „International Journal of Project Management", Vol. 34, pp. 559-569.
[23] Springer A. (2013), Kompetencje wymagane wobec kierowników zespołów projektowych - ocena potencjału pracowników, „Przedsiębiorczość i Zarządzanie”, Tom XIV, Zeszyt 11, Część I, s. 193-206.

[24] Stoof A., Martens R., van Merriënboer J., Bastiaens T. (2002), The Boundary Approach of Competence: A Constructivist Aid for Understanding and Using the Concept of Competence, „Human Resource Development Review”, Vol. 1, pp. 345-365.

[25] Trocki M. (2012), Nowoczesne zarządzanie projektami, PWE, Warszawa.

[26] Wachowiak P., Gregorczyk S., Grucza B., Ogonek K. (2004), Kierowanie zespołem projektowym, Difin, Warszawa.

[27] Wickramasinghe V., De Zoyza N. (2009), A Comparative Analysis of Managerial Competency Needs Across Areas of Functional Specialization, „Journal of Management Development", Vol. 28, No. 4, pp. 344-360.

[28] Wieczorkowska G., Wierzbiński J. (2011), Statystyka od teorii do praktyki, WN SCHOLAR, Warszawa.

[29] Wood R., Payne T. (2006), Metody rekrutacji i selekcji pracowników oparte na kompetencjach, Oficyna Ekonomiczna, Kraków.

\section{Competences of Project Participants in Light of Empirical Research}

\section{Summary}

The basic objective of the study is to examine, on the basis of empirical studies, the assessment related to the importance of the characteristics of a typical project manager and the competence level of people involved in projects, i.e. project manager, project portfolio manager and project team. The first part of the article presents - identified based on literature studies - types of competences and personal characteristics of the project manager, and in the second part - results of empirical research carried out among participants of projects implemented in organisations of various types. The presented results relate to two research areas: (1) assessing the importance of the characteristics of the model project manager, (2) competence level of people involved in projects, i.e. project manager, project portfolio manager and project team. The obtained results indicate the most desirable features of the project manager, which according to the respondents include elements related to conceptual competences, i.e. intelligence and independence of thinking, energy and consistency in action, and the ability to perceive complex situations comprehensively. On the other hand, the assessment of competences allowed to identify those features which are the most desirable in view of the function performed in the projects - in the project team of respondents, they pointed primarily to technical competences, project manager's managerial and interpersonal competencies, while in case of the project portfolio manager to managerial and political competences.

\section{Keywords}

competencies, project manager, project team, project portfolio manager 